\title{
UGT1A1 Polymorphism Positive
}

National Cancer Institute

\section{Source}

National Cancer Institute. UGT 1A1 Polymorphism Positive. NCI Thesaurus. Code C156014.

An indication that polymorphism of the UGT 1A1 gene has been detected in a sample. 